\title{
Türkiye’de Döviz Mevduatları Bağlamında Para İkamesi Sorunu ve Para Politikalarının Etkinliği
}

\begin{tabular}{|c|c|} 
K. Batu TUNAY ${ }^{1}$ \\
\begin{tabular}{|c|c|}
\hline Gönderim Tarihi & $\frac{\text { Kabul Tarihi }}{28.12 .2021}$ \\
\hline 11.08 .2021 &
\end{tabular}
\end{tabular}

Önerilen Atıf / Suggested Citation:

Tunay, K. B. (2022). Türkiye'de Döviz Mevduatları Bağlamında Para İkamesi Sorunu ve Para Politikalarının Etkinliği. Bankacılık ve Finansal Araştırmalar Dergisi, 9(1), 57-73.

$\ddot{O} z$

Bu çalışmada, banka sistemindeki döviz mevduatlarının artışına dayalı para ikamesi süreci analiz edilmekte ve Türkiye örneği üzerinden bu sorunun para politikalarının etkinliğine yansımaları değerlendirilmektedir. Çalışmada, Mizen 'in (1999) teorik modeli temel alınarak geliştirilen eşanlı denklem sistemi, Türkiye için tahmin edilmiştir. 2002-2021 dönemini kapsayan aylık verilerle yapılan analizler, Mizen modelinin temel önermelerinin Türkiye'de de geçerli olabileceğini göstermektedir. Yüksek ve kronik enflasyon nedeniyle portföylerinde dövize daha çok yer veren yerleşikler, döviz varlıklarını banka sisteminde tutmayı tercih etmektedir. Ama bir kur şoku yaşanması halinde bu durum değişebilir. Döviz varlıkları banka sistemi içinde kaldıkça, ikame süreci merkez bankasınca yönetilebilir ve kur rejimi korunabilir. Bu süreçte rezervlerin teminat işlevi ve zorunlu karşılık oranlarının dengeleyici işlevi çok önemlidir. Rezervlerin erimesi ve/veya zorunlu karşılık politikasının yanlış yönetilmesi halinde, spekülatif kur atakları yaşanması durumunda, döviz mevduatlarının banka sistemi dışına kaçması ve para politikalarının etkinliğinin zayıflaması kaçınılmaz olacaktır. Böyle bir süreç, bir kur krizine hatta kısa bir gecikmeyle buna eşlik eden bir banka krizine evrilebilir.

Anahtar Kelimeler: Para ikamesi, döviz mevduatları, para politikaları, eşanlı denklem sistemleri

Jel Kodları: C32, E52, E58

\section{Currency Substitution Problem and Efficiency of Monetary Policy in the Context of Foreign Currency Deposits in Turkey}

\begin{abstract}
In this study, the currency substitution process based on the increase in foreign currency deposits in the banking system is analyzed and the reflections of this problem on the effectiveness of monetary policies are evaluated through the example of Turkey. In the study, simultaneous equation system developed based on Mizen's (1999) theoretical model was estimated for Turkey. Analyzes with monthly data covering the period 2002-2021 show that the basic propositions of the Mizen model may also be valid in Turkey. Residents, who have more foreign currency in their portfolios due to high and chronic inflation, prefer to keep their foreign currency assets in the banking system. However, this may change in the event of a currency shock. As long as foreign exchange assets remain within the banking system, the substitution process can be managed by the central bank and the exchange rate regime can be maintained. In this process, the collateral function of reserves and the balancing function of required reserve ratios are very important. In case the reserves are melted and the reserve requirement policy is mismanaged, in case of speculative exchange rate attacks, it will be inevitable for foreign currency deposits to escape from the banking system and
\end{abstract}

\footnotetext{
${ }^{1}$ Prof. Dr., Marmara Üniversitesi Bankacılık ve Sigortacılık Yüksekokulu, Sermaye Piyasası ve Borsa Bölümü, batu.tunay@marmara.edu.tr, ORCID ID: 0000-0002-9040-5831.
} 
weaken the effectiveness of monetary policies. Such a process could evolve into a currency crisis or, with a short delay, an accompanying bank crisis.

Keywords: Currency substitution, foreign currency deposits, monetary policies, simultaneous equation systems

Jel Codes: C32, E52, E58

\section{Giriş}

Kronik yüksek enflasyon sorunu yaşanan gelişmekte olan ülkelerde, gelir ve servetlerinin alım gücünü korumak isteyen ekonomik birimler milli paradan kaçmakta ve portföylerinde değeri istikrarlı varlıklara yer vermeyi tercih etmektedirler. Milli para sadece mübadele için ve yeteri kadar bulundurulmakta, gelirin bunun haricindeki kısmı genellikle yabancı para, altın gibi varlıklara çevrilmektedir. Böyle bir süreçte, merkez bankasının parasal kontrolü zayıflamakta, para politikalarının bağımsızlığı ve etkinliği giderek azalmaktadır. Bunun para otoritelerinin hareket alanlarını kısıtlayan önemli bir sorun olduğuna kuşku yoktur. Para ikamesi veya dolarizasyon olarak adlandırılan bu sorun gelişmekte olan ekonomilerde oldukça yaygındır ve buna bağlı olarak zaman içinde teorik ve uygulamalı çalışmalardan oluşan oldukça geniş bir literatür oluşmuştur.

İki ülkenin para birimleri arasındaki değişim oranını belirleyen kur, bu ülkelerin nispi enflasyon oranlarının bir fonksiyonudur. Dolayısıyla bir ülkede enflasyon oranının artması, o ülkenin para biriminin diğerine karşı değer yitirmesine, yani kurun artmasına yol açacaktır. Enflasyonun kurlar üzerindeki bu doğrudan etkisi kadar ekonomik birimlerin artan döviz talepleri de kur artışında etkili olur. Diğer bir deyişle, para ikamesi kurların artış eğilimini güçlendirebilir. Bu nedenle para ikamesi literatürünün önemli bir bölümü milli paradan kaçışın politik etkilerine odaklanmıştır. Özellikle küçük dışa açık ekonomilerde para ve enflasyon arasındaki ilişki irdelenmektedir. Bu bağlamda yüksek enflasyon koşulları altında, ekonomik birimlerin ulusal para yerine yabancı parayı kullanmalarının sonuçları analiz edilmektedir. Nispeten az sayıda çalışma ise, döviz mevduatlarına ve bunların etkilerini incelemeye yöneliktir. Oysa ekonomik birimlerin büyük bölümü, ciddi siyasi ve ekonomik riskler olmadıkça varlıklarını yabancı para cinsinden mevduatlar olarak ulusal banka sisteminde tutmaktadır. Diğer bir deyişle, ekonomik birimler varlıklarının alım gücünü korumak istemekte, ama çok ciddi bir güven sorunu olmadıkça dövizlerini banka sisteminden çekmemekte veya yurtdışına transfer etmemektedir. Günlük alışverişlerini de milli parayla sürdürmeye devam ederler. Hal böyle olunca, banka sistemindeki döviz mevduatlarına dayalı bir dolarizasyon olgusu ve para otoritelerinin bunu yönlendirmek için efektif politikalar izlemesi konuları önem kazanmaktadır.

Türkiye 1970'lerdeki Petrol Krizi döneminden 2000'lerin başına kadar yüksek ve kronik enflasyonist baskılar yaşamıştır. Yapısal ekonomik sorunların sonucu olan bu süreç, ekonomik birimlerde güçlü bir enflasyon hafizası oluşmasına neden olmuştur. 2002 sonrasında makro ekonomik koşulların düzelmesi ile fiyat istikrarının sağlanmış ve 2017'ye kadar enflasyon oranları makul seviyelerde seyretmiştir. Ancak bu tarihten sonra fiyatlar genel düzeyi yeniden bir artış eğilimine girmiştir. Özellikle üretici fiyatlarının tüketici fiyatlarına oranla daha yüksek olması, şayet tüketici fiyatları yapay olarak baskılanmıyorsa, süreç üzerinde arz yönlü baskıların veya maliyet baskılarının daha önemli olduğu şeklinde değerlendirilebilir.

Uzun bir fiyat istikrarı döneminden sonra yeniden bir enflasyonist sürece girilmesi, ekonomik birimlerin enflasyon hafızasını canlandırmış ve servetlerinin alım gücünü korumak isteyen ekonomik birimlerin portföylerinde yabancı paranın ağırlığının tekrar yükselmesine neden olmuştur. Böyle bir süreçte, ekonomik birimlerin yabancı para mevcutlarının banka sisteminde tutulması, para politikalarının bağımsızlığı açısından nispeten olumludur. Enflasyonun artış eğiliminde olması, ekonomik birimlerin döviz taleplerini yükseltse bile, en azından bir süreliğine daha dövizin banka sisteminin dışına çıkmasına neden olmayacaktır. Ancak siyasi veya ekonomik 
nedenlerle ekonomik birimlerin döviz mevduatlarının akıbetine dair şüpheye düşmesi daha dramatik değişmelere neden olabilir. Sisteme dair bir güven bunalımı, döviz mevcutlarının banka sisteminin dışına çıkmasına, daha da kötüsü yurtdışına transfer olmasına yol açabilir. Bugüne dek mudileri döviz mevduatlarını banka sisteminden toplu olarak çekmeye iten bir panik veya güven bunalımı hiç yaşanmamıştır. Ancak Şekil 1 ve Şekil 2 incelendiğinde, kurlarla döviz mevduatları arasındaki güçlü ilişki ve son dönemde meydana gelen kur şoklarını takiben geçici mevduat düşüşleri olması dikkat çekicidir. Örneğin 2018 Ağustos ayındaki kur şokunun ardından hem yabancı para hem de TL mevduatlar dört ay boyunca düşmüştür. Bu geçici ve sınırlı bir mevduat çıkışı olarak değerlendirilebilir. Benzer bir durumun $2021 \mathrm{Kas} ı m$ ayında meydana gelen aşırı kur artışlarını takiben gözlenmesi olasıdır. Ancak bu hareket henüz tamamlanmadığından kesin bir yargıya varmak da güçtür.

Şekil 1. Yabancı Para Banka Mevduatlarındaki Değiş̧im ile Dolar Kurundaki Değiş̧im Arasındaki İlişki (2017:1 - 2021:11)

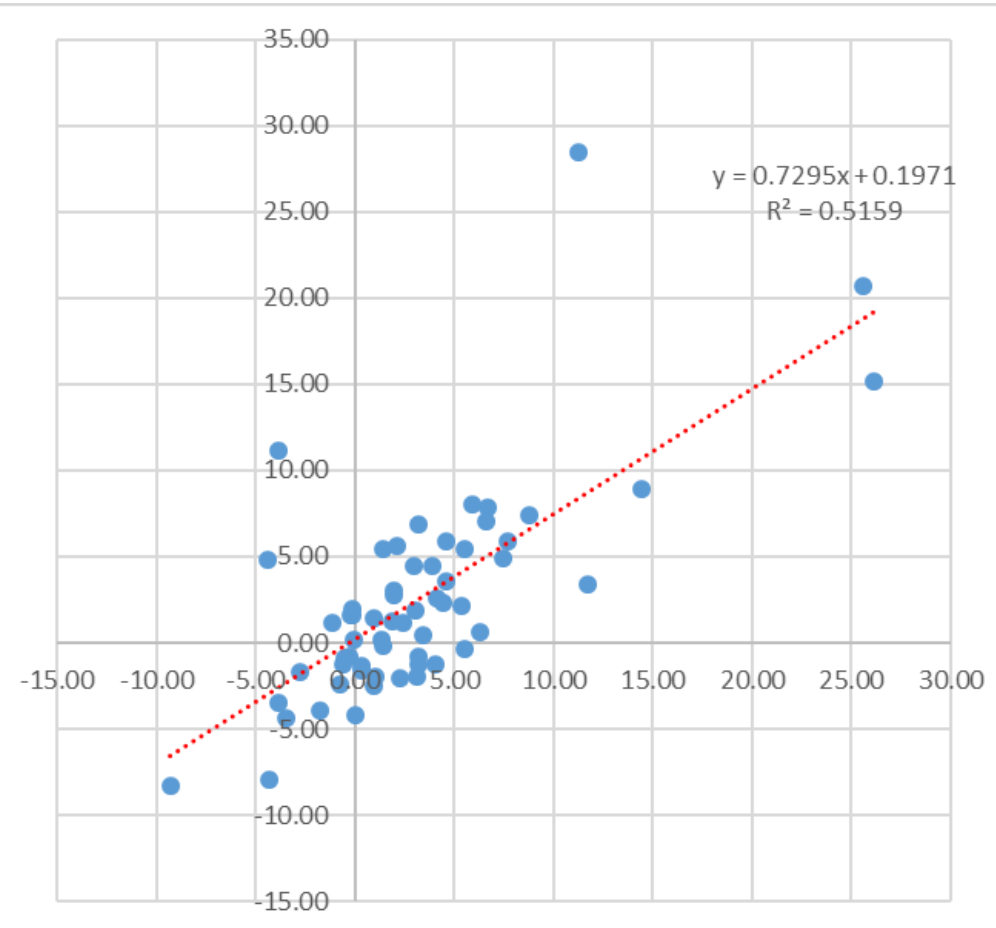

Böyle bir süreçte merkez bankasının döviz rezervlerinin önemli bir teminat olduğuna şüphe yoktur. Rezerv miktarının makul oranlarda olması, ekonomik birimlerin güvenini sağlamlaştıracağ1 gibi, olası kur şoklarına karşı merkez bankasına müdahale şansı da verecektir. Ancak 2018 sonrasında merkez bankası rezervlerinde gözlenen ciddi düşüş, bu müdahale olanağını daraltmış, olası bir kur şokunun kur krizine dönüşme ihtimalini arttırmıştır. $\mathrm{Bu}$ gelişmeler döviz mevduatlarının banka sisteminden kaçış riskini de yükseltmiştir. Türk banka sisteminde döviz mevduatların toplam mevduatlara oranının oldukça yüksek olması, ek olarak yurtdışı kaynaklı sendikasyon kredilerinin artması, toplam döviz yükümlülüklerinin ciddi oranlara ulaşmasına neden olmuştur. Bu gelişmeler bankaları kur riskinin etkilerine daha açık hale getirdiğinden, olası bir kur krizinin banka krizine evrilme olasılığı da vardır.

Mizen'in (1999) geliştirdiği teorik model, Türkiye'de gözlenen döviz mevduatlarına dayalı bir para ikamesi sürecinin etkileri bakımından önemli bir tartışma zemini oluşturabilir ve çözümler konusunda yol gösterebilir. Söz konusu model, her ne kadar sabit kur rejiminin geçerli olduğu 
hipotetik bir ekonomi için geliştirilmişse de muhtemel spekülatif kur atakları karşısında kur rejiminin korunması konusunda önemli ipuçları sunmaktadır. Bu bağlamda, döviz mevduatlarının banka sistemi dışına kaçmasını engellemeye ve merkez bankası rezervlerinin korunmasına dair bir yol haritası sunmaktadır.

Şekil 2. Kur Hareketleri ve Ticari Banka Sistemindeki Mevduatların Gelişimi

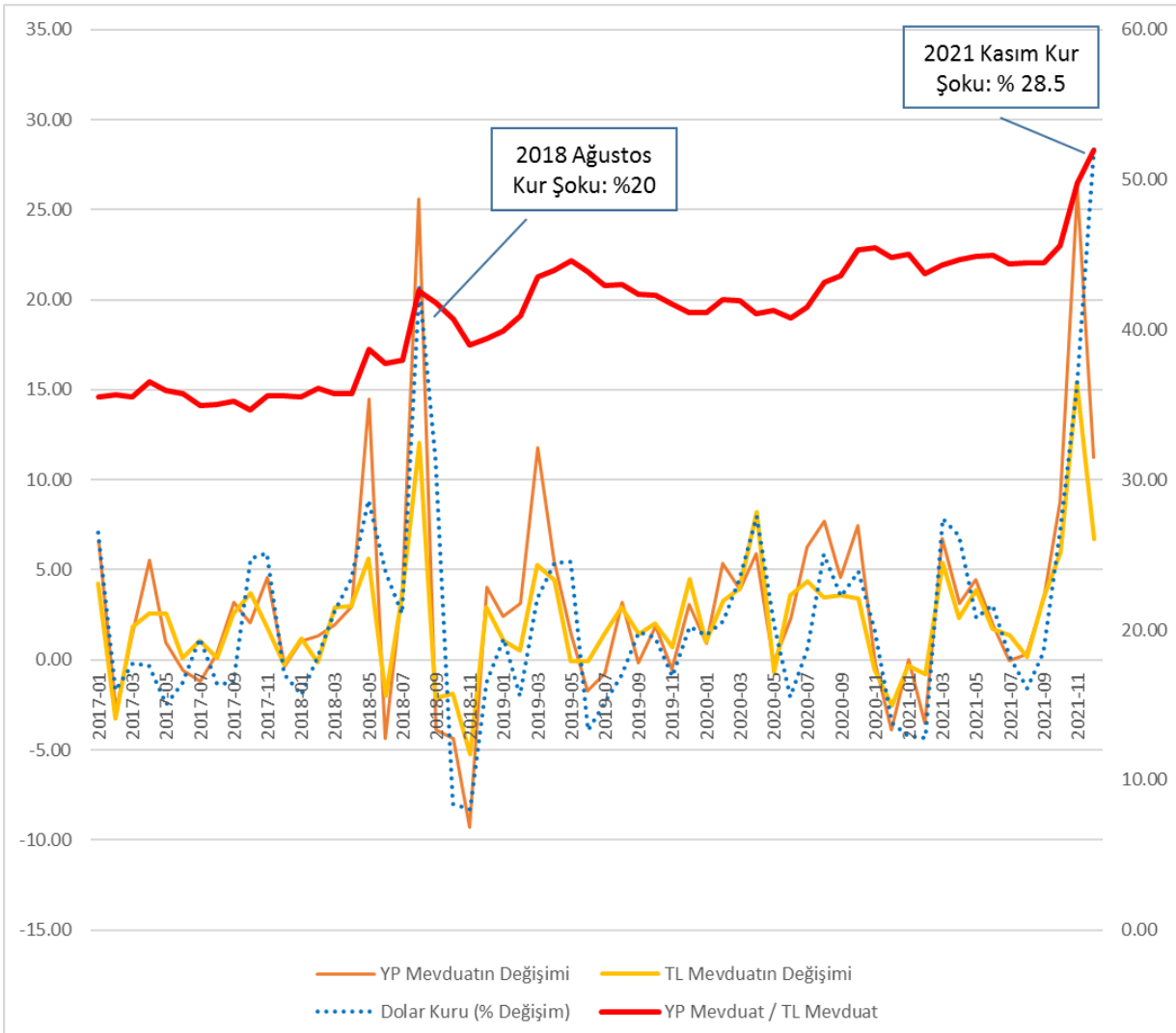

Yukarıda yapılan tespit ve değerlendirmeler 1şı̆̆ında, bu çalışmada Mizen'in (1999) modeli temel alınarak geliştirilen denklem sistemi Türkiye için ekonometrik olarak test edilmiştir. Böylece yüksek enflasyonun neden olduğu para ikamesi sürecinde banka sistemindeki döviz mevduatlarının rolüne, olası bir kur şokunu takiben doğabilecek sorunlara ve merkez bankasının yapabileceklerine 1 şık tutulması hedeflenmektedir. Çalışma, giriş ve sonuç bölümleri hariç tutulursa üç ana bölümden oluşmaktadır. İlk bölümde ana hatlarıyla Mizen'in modeline değinilmekte, ikinci bölümde döviz mevduatlarına dayalı para ikamesi veya dolarizasyon süreci konusundaki deneysel çalışmaların bulguları değerlendirilmektedir. Üçüncü bölümde ise, geliştirilen eşanlı denklem sistemi alternatif tahminciler kullanılarak çözülmüş ve ulaşılan bulgular tartış1mıştır.

\section{Teorik Temeller: Mizen (1999) Modeli}

Spekülatif ataklar üzerine ilk çalışma Flood ve Garber'in (1984) makalesidir. Flood ve Garber, döviz kurunun para miktarının fonksiyonu olduğu bir model geliştirmişlerdir:

$M M_{t t}=\beta \beta S S_{t t}-\alpha \alpha S S_{t t}$ 
(1) numaralı eşitlikte $M M_{t t}$ para arzını, $S S_{t t}$ nominal döviz kurunu ve $S S_{t t}$ nominal kurun zamana göre türevini simgeler. Eşitlikte, $\beta \beta$ nominal kurun, $\alpha \alpha$ ise bunun zamana göre türevinin para arzına etkisini yansıtan parametrelerdir ve sabit oldukları varsayılmıştır (Flood ve Garber, 1984: 3). Merkezbankasının bakış açısından para arzını, yurtiçikredi $D D_{t t}$ verezervleri $R R_{t t}$ içeren birözdeşlik olarak ifade etmek de olasidır:

$M M_{t t}=D D_{t t}-R R_{t t}$

Dolayısıyla (1) ve (2) numaralı eşitlikler kullanılarak kurlar ile krediler ve rezervler ilişkilendirilebilir: $\beta \beta S S_{t t}-$ a $\alpha S_{S_{t}}=D D_{t t}-R R_{t t}$. Mizen (1999), bu modeli döviz kurunun, merkez bankas1 rezervlerinin ve para stoğunun spekülatif bir atak karşısında nasıl hareket edeceklerini göstermek için geliştirmiştir. Kusursuz bir öngörü yapılabileceği ve sabit kur rejiminin kullanıldığı varsayımları altında, Mizen yurtiçi krediler arttıkça rezervlerin bu artışla aynı oranda azalacağını öne sürmüştür.

Mizen'e göre; sabit kur rejimi, ancak spekülatif ataklar karşısında bunu korumak için merkez bankası rezervlerini kullanılırsa sürdürülebilir. Bununla beraber sınırlı rezervler, her dönemde yurtiçi kredi hızına eşit oranda azalacak ve zamanla tükenecektir. Dolayısıyla merkez bankasının rezervlerinin başlangıçtaki düzeyi biliniyorsa, spekülatörlerin rezervler tükenmeden merkez bankasının döviz kurunu ne kadar süreyle sabit tutabileceğini tahmin etmesi mümkündür. Rezervler sıfıra düştüğünde, döviz kuru sabit kalmayacak ve yeni bir düzeye sıçrayacaktır. Bir başka deyişle sabit kur rejimini sürdürme imkânı kalmayacak ve kurlar dalgalanmaya başlayacaktır. Spekülatörlerin kurlardaki her artışı karlı bir arbitraj fırsatı olarak görecekleri varsayılırsa, sabit kur rejiminin çöküşü, gölge kurun sabit kura eşit olacağı noktadan önce gerçekleşecektir.

(1) numaralı eşitlik kullanılarak gölge döviz kurunun değerlenmesi ve kurun resmi kurla eşitlenmesi ile spekülatörler sabit kur rejiminin çöküş zamanını hesaplayabilirler. Çöküş zamanı (collapse time $/ t t_{c c}$ ), rezervlerin başlangıçtaki düzeyinin bir fonksiyonu olarak tanımlanabilir:

$t_{c c}=\left[\left(\beta \beta \overline{S S}-D D_{0}\right) / \mu \mu\right]-(\alpha \alpha / \beta \beta)$

Flood ve Garber (1984: 3-4), (2) numaralı eşitlikten hareketle detaylarına burada girilmeyecek ara hesaplama adımlarından sonra yukarıdaki eşitliği tanımlamıştır. (3) numaralı eşitlikte, SS sabit kur düzeyini, $D D_{0}$ başlangıçtaki yurtiçi kredi düzeyini, $\mu \mu$ yurt için kredi artışını simgeler. Ayrıca $R R_{0}=\beta \beta S \bar{S}-D D_{0}$, yani merkez bankası rezervlerinin başlangıçtaki düzeyidir. Bu kurguda merkez bankası rezervlerindeki eksiği tamamlayabilir ve rezervlerini başlangıçtaki düzeyine ulaştırabilirse, sabit kur rejiminin çöküşü geciktirilebilir. Ancak yurtiçi kredi büyümesi $(\mu \mu)$ artarsa veya politik otorite tarafından uygulanan politikalarla arttırılırsa çöküş süreci öne çekilecektir.

Orijinal spekülatif atak modelinde, yerleşikler tarafindan tutulan yabancı varlıklara yer verilmemiştir. Mizen (1999), spekülatif atağa açık ekonomilerde yurttaşların milli bankalarda yabancı para mevduat tutmalarının yaygın bir özellik olduğuna vurgu yapar. Ona göre, yurttaşlar yabancı para birimi ile yerel para birimi arasında bir seçim yapacaklar ve aynı zamanda para mevcutlarını nerede tutacaklarına da karar vereceklerdir. Bu bağlamda iki olası durum söz konusudur; ellerindeki dövizleri yurtiçinde takas etmeleri veya bunları yurtdışına transfer etmeleri (yatırmaları). Böylece döviz kuru rejiminin kırılganlığı artacaktır.

Yurttaşlar döviz tutmaya karar verirlerse, para otoriteleri döviz mevduatlarının yerel banka sisteminde kalmasını teşvik ederek döviz pozisyonunu korumaya çabalayacaktır. Döviz yerel banka sisteminde tutulduğu sürece, merkez bankası sabit döviz kuru rejimini korumak için zorunlu karşılık politikası ile bunların bir bölümünü resmi rezervleri desteklemekte kullanabilir. Bu kabulden hareket eden Mizen (1999), yerleşiklerce döviz mevduatları tutulması ve merkez bankasının zorunlu karşılık politikası ile bunları yönlendirmesi varsayımlarını Flood ve Garber'in (1984) spekülatif atak modeline dahil etmiştir. 
Mizen, yurtiçi kredilerin artmasının ve enflasyon nedeniyle kurlardaki artışın yurttaşların birikimlerini yabancı para cinsinden tutmaya teşvik ettiğini varsayar. Ancak yurttaşların mübadeleler için de bir miktar milli parayı elde tutmaları gerekecektir. Tahvil yerine para olarak tutulacak servetin oranın belirleyen likidite kararı, bu likiditenin hangi oranda milli veya yabancı para cinsinden tutulacağına ilişkin alt kararları da kapsar. Enflasyon nedeniyle milli paranın alım gücünün düşmesi, yerleşikleri döviz tutmaya itecek ve kur rejiminin çökmesine zemin hazırlayacaktır.

Yurttaşların yabancı para cinsinden mevduatları konusunda tercihte bulunmalarına izin verildiğinde, bunların mevduatlarını yurtdışına kaydırma çabaları nedeniyle kur rejiminin çöküş tarihi öne çekilebilir. Merkez bankası mevduatların yurtdışına aktarılmasının zararları karşısında hızla sınırlandırmalara gitse bile, yurttaşların paralel piyasalar kanalıyla paralarını yurtdışına taşıma olasılığı vardır. Bu nedenle merkez bankasının yurttaşların portföy tahsisi kararlarını iyi analiz etmesi ve politikalarını buna göre oluşturması gerekmektedir. Özetle Mizen (1999), modelinde merkez bankasının zorunlu karş1lık politikası ile yurttaşların yurtiçi portföy kararları arasındaki etkileşime odaklanmıştır. Yurttaşlar yabancı para cinsinden mevduatlarını yurtiçinde tutmayı yeğlerse, enflasyonist bir çevrede bu dövize olan taleplerini azaltmaz ve kur rejimi üzerindeki baskıyı ortadan kaldırmaz. Ancak merkez bankası zorunlu karşılıklar yoluyla kendi döviz rezervlerini desteklemek ve kur istikrarını korumak için bu mevduatları kullanabilir. Mizen'e göre, böyle bir mekanizma kur istikrarının daha uzun süre korunmasına ve kur rejiminin çöküşünün ertelenmesine yardımcı olur. Dolayısıyla spekülatif bir kur atağı karşısında istikrar sağlayabilir.

Merkez bankasının bilançosu dikkate alındığında, aktifler yurtiçi krediler $\left(D D_{t t}\right)$, uluslararası

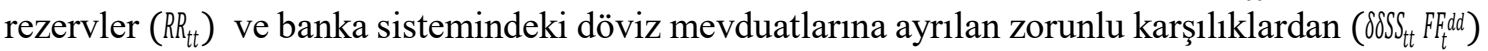
oluşacaktır. Pasifler ise, yurtiçi döviz varlıklarına karşı tutulan zorunlu rezervler $\left(\delta 8 S_{t t} S_{t} F_{t}\right)$, yurtiçi aktifler ( $(\varepsilon M M D D)$ ve dolaşımdaki paradan (MMCC) meydana gelecektir:

Yerel Merkez Bankasının Bilançosu

\begin{tabular}{c|c} 
Aktifler & Pasifler \\
\hline$D D_{t t}$ & $M M^{C C}$ \\
$R R_{t t}$ & $\varepsilon \varepsilon M M^{D D}$ \\
$\delta \delta S S_{t t} F F d d$ & $\delta \delta S S_{t t} F F d d$
\end{tabular}

Bilindik muhasebe uygulamalarında yabancı para mevduatlara karşı ayrılan zorunlu karşılıklar kayıtlı uluslararası rezervlerin bir parçası olarak dikkate alındığından, Mizen modelinde para arzı denklemine zorunlu karşıllıkları da eklemiştir:

$M M_{t t}=D D_{t t}+R R_{t t}+\delta \delta S S_{t t} F F d d$

Para otoritelerinin zorunlu karşıllı oranı ( $8 \delta)$ tercihi, yurttaşların yabancı para mevduatlarının miktarını ve kur rejiminin sürdürülebilirliğini etkiler. Merkez bankasının döviz rezervlerindeki düşüş oranını ve dolayısıyla kur rejiminin çöküş zamanını etkilediğinden $\delta \delta$ seçimi, yurtiçi kredi büyümesini yansıtan $\mu \mu$ kadarönemlidir.

Yurttaşların portföylerinde döviz tutmalarının rezervlerde neden olduğu düşüş oranı ve bunun kur sisteminin çöküşü üzerindeki etkisi hesaplanabilir. (1) ve (4) numaralı eşitlikler kullanılarak kur rejiminin çöküşzamanını yansıtan (3)numaralı eşitlikteki $\beta \beta S S$ terimi hesaplanabilir: $\beta \beta S S=\left(D D_{t t}+\right.$ $\left.R R_{t t}+\delta \delta S \bar{S} F f_{t}^{d d}\right) . B u$ hesaplama, ileride açıklanacak olan ve rezervlerdeki değişimi yansıtan (9) numaralı eşitliğin elde edilmesine de temel oluşturur.

Mizen'in modelinde, reel kaynakların negatif bir fonksiyonu olan parasal hizmetlerin verimlilik ve likidite hizmetlerinden bağımsız oldukları kabul edilir. Parasal hizmetler (MMSS), yurttaşların 
yurtiçinde ve yurtdışında tuttukları yabancı para miktarının, resmi döviz kurunun ve yurtiçi fiyat düzeyinin bir fonksiyonudur:

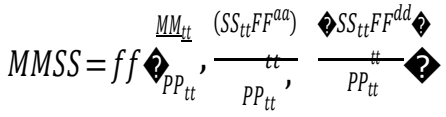

(5) numaralı eşitlikte $F F_{t t}^{a a}$ yerleşiklerce yurtdışında tutulan yabancı parayı, $F F^{d d}$ yerleşiklerce $_{t t}$ yurtiçinde tutulan yabancı parayı, $S S_{t t}$ resmi kuru, $P P_{t t}$ yurtiçi fiyat düzeyini simgelemektedir. Fonksiyonun tüm unsurları para arzını pozitif etkiler. Detayları burada açıklanmayacak bir dizi varsayımdan hareketle Mizen (1999), parasal hizmetler fonksiyonunu Cobb-Douglas fonksiyonu şeklinde tanımlamıştır:

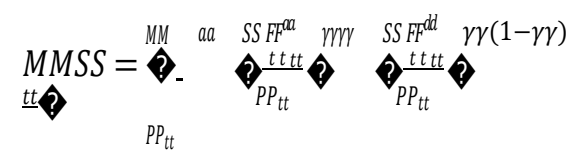

Yabancı para cinsinden sağlanan parasal hizmetler $\gamma \gamma$ 'ya bağlıdır. Ama yurtiçindeki para mevcutları zorunlu karşılıklara tabi olduğundan, para hizmetleri $\delta \delta$ arttıkça azalacaktır. Bu durum yurtiçindeki döviz mevduatlarınca sağlanan hizmetlerin $\delta \delta$ 'dan negatif etkileneceğini gösterir. Daha açık bir deyişle, merkez bankası zorunlu karşılık oranlarını arttırdıkça yurtiçi döviz mevduatlạrının sağladığı likidite hizmetleri düssecektir. $\mathrm{Bu}$ süreç devam ettikçe tüm likidite hizmetleri ortadan kalkacaktır. FFaa ve $F F{ }_{t t}$ 'nin $M M_{t t}$, ye oranları, parasảl hizmetler fonksiyonundaki ağırlıklarına bağlıdır. Sağlanan parasal hizmetler $\delta$ ' ya bağlıdır:

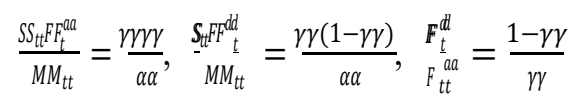

Tüm bu tanımlamaların ardından yurttaşların toplam yabancı para mevcutları $F F_{t t}^{x X}=F F_{t t}^{a a}+F F_{t t}^{d d}$ olarak hesaplanabilir ve bundan hareketle yurtiçindeki döviz mevduatları da tanımlanabilir:

$\underset{t t}{F F d d}=(1-\delta \delta) \underset{t t}{F x X}$

Böyle bir kurguda, zorunlu karşılık oranı sıfira düşürülürse, yurtiçi yabancı para mevduatlar toplam yabancı para mevduatlara eşit hale gelecektir: $\delta \delta=0 \Rightarrow F F_{t t}^{d d}=F F_{t t}^{x X}$ Çünkü yurttaşların yabancı paralarını yurtdışında tutmalarına gerek kalmayacaktır. Aksine zorunlu karsılık oranı bire çıartılırsa, tüm yabancı para mevduat yurtdışına akacaktır: $\delta \delta=1 \Rightarrow F F_{t t}^{a a}=F F_{t t}^{X X}$. Dolayısıyla

merkez bankasının zorunlu karş1lık oranı seçimi çok önemlidir, çünkü yurttaşların portföy tahsislerine yön verecektir. Şayet yüksek bir oran belirlenirse yurttaşlar dövizlerini yurtdışına transfer etmeye başlayacak ve kur rejimini uzun süre sürdürmek mümkün olmayacaktır.

Bununla beraber Mizen'e (1999) göre; modelin daha ileri bir analizi yapılacak olursa, bu ilk tespitlerin yanlış olduğu görülecektir. Çünkü yurttaşlar portföy seçimlerini merkez bankasından döviz satın alarak, böylece uluslararası rezervleri azaltarak yapacaklardır. Yurttaşlar döviz toplamaya hazır olan merkez bankası aracılığı ile sabit bir kur üzerinden döviz satın alırlar. $\mathrm{O}$ halde yurttaşlar döviz tuttuklarında ve döviz kuru sabit olduğundan, resmi rezervler buna eşdeğer miktarda azalmalıdır. Yabanc1 para daha sonra yerel bankalara mevduat olarak yatırılsa bile, merkez bankası sadece bundan $(1-\delta \delta)$ oranında zorunlu karşılık ayıracaktır. Kalan kısım merkez bankası için bir kayıptır ve kur rejimini desteklemek için kullanılamaz.

Mizen (1999), tüm bu açıklamalar ışı̆̆ında yurttaşların portföylerinde döviz tutmalarının rezervlerde neden olduğu düşüş oran1 ve kur sisteminin çöküşü üzerindeki etkisinin hesaplanabileceğini ileri sürmüştür. Ayrıca ona göre, kur sisteminin çöküş zamanı da hesaplanabilir. Mizen'in geliştirdiği modelin ara adımları bir yana bırakılırsa, rezervlerdeki değişim aşağıdaki gibi hesaplanmaktadır:

$R_{t t}=-\frac{\mu \mu}{(1-\gamma \gamma(1-\gamma \gamma))}$

$\mathrm{Bu}$ eşitlik, rezervlerin değişiminin bankalarca açılan yurtiçi kredilerin artış oranına ve zorunlu karşl1ık oranına bağlı olduğunu göstermektedir. Rezervler, yurtiçi kredilerin artışıyla doğru ve 
zorunlu karş1ık oranıyla ters orantılı olarak azalacaktır. Rezervlerin düşüş oranı, yurtiçi kredi artışının bir fonksiyonudur. Yurtiçi kredi genişlemesi ise, zorunlu karşılık oranları ile ölçeklendirilmiştir. Para otoritelerinin sıfır ile bir arasında seçtikleri herhangi bir zorunlu karşılık oranı $(0<\delta \delta<1)$, rezervlerin daha hızlı düşmesine neden olur. Buna karşı1ık bu oranın sıfıra veya bire eşitlenmesi, Flood ve Garber (1984) modelindeki gibi rezervlerdeki düşüş oranını en aza indirecektir. Rezervlerin daha hızlı bir oranda azalmasının sonucu, kur rejiminin çöküş zamanını kısaltacaktır. Bunu şu şekilde hesaplamak mümkündür:

$S S_{t t}=\lambda_{0}+\lambda_{1} M M_{t t}$

Yine ara hesaplama adımları bir yana bırakılırsa, (10) numaralı eşitlikten hareketle rezervlerin ve yabancı para mevcutlarının dinamikleri hesaplanabilir. Sözü edilen dinamikler zamana göre düzenlenerek kur rejiminin çöküş zamanı $\left(t t_{c c}\right)$ hesaplanabilir:

$t t_{c c}=\Omega \overbrace{}^{\beta \beta S \bar{S}-\left(D D_{0}+\gamma(1-\gamma) \overline{S S} \mathrm{SPX}\right)}-\frac{\alpha \mu}{\mu \mu} \curvearrowright$

$\mathrm{Bu}$ eşitlikte omega parametresi zorunlu karşı1lık oranından hareketle tanımlanmıştır: $\Omega=(1-$ $\delta \delta(1-\delta 8))$. Eşitlikte sıfır alt indisi ilgili değişkenin başlangıçtaki stok değerini göstermektedir. $\bar{S}$ sabit kur düzeyini simgelemektedir. Alfa ve beta ise, omega gibi eşitlikteki diğer parametrelerdir.

(11) numaralı eşitlik bize çöküşün zamanlamasının, yerel banka kredilerinin başlangıç değerine, yerli ve yabancı yerleşiklerin elindeki döviz mevcutlarına bağlı olduğunu gösterir. Köşeli parantez içindeki ifade, zorunlu karşl1ıklar sıfıra veya bire eşit olduğunda Flood ve Garber'ın (1984) modeliyle aynıdır. Yani (11) numaralı eşitlik (3) numaralı eşitlikten farksız hale gelecektir.

Şayet merkez bankası diş pozisyonunu iyileştirmek için yurtiçinde döviz mevduatlarına uyguladığı zorunlu karşılıkları bir politika aracı olarak kullanırsa, (11) numaralı eşitlikte köşeli parantez içindeki pay nispeten küçük olacağı için durumu daha da kötüleştirir. Böyle bir yaklaşım izlenirse, zorunlu karşıllı oranı sıfirla bir arasında $(0<\delta \delta<1)$ olacağından omega parametresi birin altına düşecek $(\Omega<1)$ ve Flood ve Garber modeline oranla çöküş zamanı daha hızlı gelecektir. Sıfır ve bir arasında bir zorunlu karşılık oranı uygulanması, gölge kurun daha yüksek bir oranda artmasına ve sabit orana daha çabuk eşitleneceği için çöküşün de daha hızlı gerçekleşmesine neden olacaktır. O halde merkez bankası kur rejimini korumak için zorunlu karşılık oranını belirlerken çok dikkatli hareket etmelidir. Diğer yandan, Mizen'in modeli de yurtiçi kredi hacmindeki artışın rezervlerdeki düşüşü hızlandıracağına ve kur istikrarını tehdit edeceğine vurgu yapar. Yani para otoritelerinin sadece zorunlu karşılıklar konusunda değil yurtiçi kredi hacmi konusunda da dikkatli olmaları gerekmektedir.

\section{Literatür Taraması}

Para ikamesi veya dolarizasyon literatüründe, bankaların para ikamesi sürecindeki yerine ve bu olgudan nasıl etkilendiklerine dair çalışmaların sayısı giderek artmaktadır. Bu alanda yapılan çalışmalardan önemli bir bölümü, yabancı paranın değer saklama rolüne ve dolayısıyla banka sistemindeki döviz mevduatlarına odaklanmıştır. Agenor ve Khan (1996), Mizen (1999), Alami (2001), Mikrakhor ve Zaidi (2004), Whited (2004), Brown ve Stix (2015), Bitar (2021) gibi araştırmacıların çalışmaları bu grupta sayılabilir. Bunlar yurttaşların banka sisteminde tuttukları döviz mevduatlarına ve bunların merkez bankasının para politikaları üzerindeki etkilerine odaklanmıştır. Honohan ve Shi (2003), De Nicolo vd. (2003), Arteta (2003), Gulde vd. (2004), Ramon-Ballester ve Wezel (2007), Versal ve Stavytskyy (2015) gibi araştırmacılar finansal dolarizasyona ve bu kapsamda döviz mevduatlarının yanında döviz kredilerinin etkilerine de değinmiş̧lerdir.

Mizen (1999), Alami (2001), Whited (2004) ve Bitar'ınkiler (2021) gibi kuramsal çalışmalarda, döviz mevduatlarının kur rejimi üzerindeki etkisi ele alınır. Mizen (1999), döviz mevduatları için ayrılan zorunlu karşılıkların oranı ayarlanarak merkez bankası rezervlerinin desteklenebileceğini, 
böylece olası kur şoklarına karşı kur rejiminin ömrünün uzatılabileceğini savunur. Bu bağlamda yanlış bir zorunlu karşılık politikası, banka sisteminden hatta ülkeden döviz çıkışlarına ve kur rejiminin çöküşüne neden olabilir.

Alami (2001) yabancı paranın değişim aracı veya değer saklama aracı olarak kullanımına göre kavramsal bir ayrıma gitmiştir. Ona göre; eğer yerleşikler yabancı parayı bir mübadele aracı değil de değer saklama aracı olarak görüyorlarsa, döviz mevduatlarının işlem odaklı para arzı ölçümlerine dahil edilmemesi gerekmektedir. Çünkü bu takdirde işlem odaklı para arzına dayalı analizler yanıltıcı olacaktır. Elbette yanlış analizlere dayalı para politikaları da başarıya ulaşmayacaktır. Whited (2004), Alami'nin (2001) bu kavramsal ayrımına itiraz etmiştir. Yabancı paranın yaygın olarak kullanıldığı bir ekonomide, kısa vadeli döviz mevduatlarının dar para tanımı içinde yer alması analizlerin sağlamlığını etkilemeyecektir. Whited (2004), para ikamesini işlevlerine göre yabancı para ve yabancı tahviller olarak ayrıştırarak analizlere dahil edilmesini önermiştir. Genelde siyasi ve/veya finansal istikrarsızlı artııça yabancı paranın banka sistemi dışına çıktığı gözlenmektedir. Ekonomik koşullar normal olduğunda yabancı paranın banka sistemine dahil olması daha olasidir.

Bitar (2021) ise, banka sisteminin döviz aracıllı̆ı yapmasından kaynaklanan likidite ve döviz risklerinin sistemik etkilerinin önemini vurgular. Sakin dönemlerde bankaların döviz aracıllğ yapmasının ekonomik büyümeye olumlu etkileri olsa bile, bu olgunun hala ciddi bir finansal kırılganlık kaynağı olduğunu ifade eder. Bitar (2021) çare olarak, döviz tevdiat hesaplarına ilişkin kurallar tanımlanmasının da aralarında olduğu bir dizi makro ihtiyati tedbir alınmasını önermektedir.

Agenor ve Khan (1996), Mikrakhor ve Zaidi (2004), Ramon-Ballester ve Wezel (2007), Brown ve Stix (2015), Versal ve Stavytskyy (2015) gibi araştırmacıların çalışmaları farklı ülkelerden derlenen örneklemler kullanılarak yapılan ekonometrik analizlerdir. Bunların bulguları, analiz edilen örneklem ve analiz döneminin farklı olması nedeniyle bazı farklılıklar göstermektedir. Bununla beraber, genel olarak yabancı para cinsinden mevduatların para politikalarının yönetilmesi ve finansal sistemin, özellikle de banka sisteminin istikrarı açısından önemli sorunlara neden olabileceği yönünde sonuçlara ulaşılmıştır.

Başta bankalar olmak üzere finansal aracıların bilançolarında farklı para birimlerinin bulunmasının finansal sistemin kırılganlığını arttırdığı ve parasal aktarım mekanizmasının işleyişini bozduğu konusunda genel bir fikir birliği vardır. Örneğin Honohan ve Shi (2003), dolarizasyonun bankaların faiz oranı marjları, döviz kuru geçişkenliği (exchange rate passthrough), bankaların ve banka dışı kesimin deniz aşırı döviz mevduatlarını yönlendirme eğilimleri üzerinde güçlü etkileri olduğunu göstermişlerdir. De Nicolo vd. (2003) ise, banka sistemindeki döviz mevduatlarının yüksek enflasyon koşullarında finansal derinleşmeyi teşvik ettiğini belirlemişlerdir. Arteta (2003), yüksek mevduat veya kredi dolarizasyonunun banka krizi olasılığını etkilemeyeceği sonucuna varmıştır. Gulde vd. (2004), takibe düşen krediler ve firmaların ödeme güçlüğüne düşme olasılıklarına dayalı banka kırılganlıklarının dolarizasyon nedeniyle arttığını göstermiştir. Ayrıca dolarizasyon sorunu yaşanan ekonomilerdeki sistemik likidite riskinin ülke veya banka riskiyle ilişkili olduğu da saptanmıştır. Çünkü mudiler döviz mevduatlarını bankalardan çekebilmekte veya döviz tasarruflarını yurtdışına transfer edebilmektedir. $\mathrm{Bu}$ da ister istemez dolarizasyon olan ülkelerde merkez bankalarının çok daha efektif para politikaları izlemeleri gerektiği anlamına gelmektedir.

Ramon-Ballester ve Wezel (2007) ise, Latin Amerika örneği üzerinden bankaların dolarizasyon olgusundan nasıl etkilendiğini araştırmışlardır. Bu bağlamda, bankaların döviz pozisyonlarının, yani döviz cinsinden borçlarının ve varlıklarının hangi faktörlerden etkilendiklerini ele almışlardır. Özellikle dolarizasyon ve politik riskin bankaların döviz pozisyonlarını nasıl etkilediğine odaklanmışlardır. Yaptıkları analizler sonucunda, bankaların döviz pozisyonlarının risk-getiri değerlendirmelerinin ve aşırı iç kredi talebinin fonksiyonu olduğunu saptamışlardır. Ulaştıkları bulgular, politik riskteki artışın sermaye çıkışlarını tetiklediğini, ancak yüksek döviz 
mevduatlarının politik risk artışı kaynaklı sermaye kaçışlarının olumsuz etkisini azalttı̆̆ını göstermektedir. Yüksek oranda dolarize olmuş ekonomilerde siyasi belirsizliğin devam etmesi halinde dolarizasyonu azaltma stratejilerinin uygulanmasında dikkatli olunması gerekmektedir. Çünkü bu durumda ciddi kur çöküşleri, yani kur krizleri riski doğabilir. Dolarizasyonu azaltmak için alınacak önlemler, özellikle döviz mevduatlarının payını düşürecek eylemler, güçlü sermaye çıkışları karşısında kurların hızla artmasına yol açabilir.

Versal ve Stavytskyy (2015), Ukrayna'da finansal dolarizasyonun nedenlerini ve sonuçlarını aylık verilere dayalı bir örneklem üzerinden incelemiştir. Çalışmada yerleşiklerin döviz cinsinden mevduatları ve kredileri ele alınmıştır. Döviz kurları istikrarlı olduğunda, mevduat dolarizasyonu kayıt dışı ekonomiden banka sistemine fon akışına yol açmakta, kredi dolarizasyonu ise enflasyon beklentileri nedeniyle yerel para cinsinden yapılamayan uzun vadeli krediler açılmasına imkân vermektedir. Ancak kur istikrarı bozulduğunda bu olumlu etkiler tersine dönmekte, artan kur, kredi ve likidite riskleri nedeniyle banka sistemi zarar görmektedir. Yapılan analizin bulguları, finansal dolarizasyonun olumsuz etkilerinin olumlu etkilerine galebe çaldığ 1 yönündedir. Bunun nedeni olumlu etkilerin ekonominin koşullarına ve kur oynaklığına bağlı olmasıdır. Kalıcı ekonomik istikrar sağlanamadığında ve ani kur artışlarına neden olabilecek dış şokların etkileri azaltılamadığında dolarizasyonun olumsuz etkilerini önlemek zordur. Bu durumda da banka sistemi ciddi kayıplara maruz kalacaktır. Çünkü yabancı mevduatların yüksek olması ciddi bir kırılganlık kaynağıdır.

Toparlanacak olursa, dolarizasyonla aktif bir şekilde mücadele edilecekse, bu ancak politik istikrar sağlandıktan sonra yapılmalıdır. Politik istikrar sağlanmadan atılacak adımlar hem etkisiz hem de tehlikeli olabilir.

\section{Ekonometrik Analiz}

\subsection{Analiz Edilecek Modelin Yapısı}

Mizen'in (1999) modeli sabit kur rejimi üzerinden döviz mevduatlarının para politikası kararları açısından önemini ve etkilerini göstermektedir. Bununla beraber, Türkiye gibi yarı kontrollü veya yönlendirilmiş dalgalı kur rejimi uygulanan ekonomiler için para ikamesi olgusu açısından önemli çıkarımlar yapmaya imkân verecektir. Mizen, spekülatif kur atakları karşısında kur rejiminin korunabilmesi için merkez bankası rezervlerinden müdahale edilmesi gerektiğine vurgu yapmıştır. Diğer bir deyişle kur istikrarı açısından merkez bankası rezervlerinin kilit bir rolü ve önemi vardır. Rezervler eridiğinde kurları hedeflenen seviyelerde tutmak mümkün olmayacaktır. Mizen (1999), yurtiçi kredi büyümesinin uluslararası rezervleri azalttığını, banka sisteminde tutulan döviz mevduatlarının uygun politik adımlarla döviz rezervlerin düşmesini engelleyebileceğini savunmuştur. Merkez bankası uygulayacağı doğru bir zorunlu karşıllk politikası ile resmi rezervlerin seviyesi korunabilir. Böylece yerleşiklerin dövize olan talepleri düşmese bile, kurların daha da artması sınırlanarak dolaylı şekilde dövizin banka sistemi dışına veya yurtdışına çıkışı engellenebilir. Para ikamesinin gerilemesi ise, ancak enflasyon oranlarının kalıcı bir şekilde gerilemesine ve ekonomik birimlerin milli paraya olan güvenlerinin artmasına bağlıdır.

Bu tespit ve değerlendirmeler ışığında aşağıdaki fonksiyonel ilişkiler tanımlanabilir:

$R_{\mathrm{tt}}=f f \curvearrowright \mu \mu, F^{d d}, \delta \delta \vartheta, f f^{\mu \mu}<0, f f^{F F^{d d}}>0, f f \gamma>0$

(12) numaralı eşitlik, merkez bankası rezervlerinin $\left(R R_{t t}\right)$, yurtiçi kredi büyümesinin $(\mu \mu)$ negatif, yerleşiklerin yurtiçi döviz mevduatları $\left(F F_{t}^{d d}\right)$ ve döviz mevduatlarına uygulanan zorunlu karşıllı oranlarının ( $(\delta)$ pozitif bir fonksiyonu olduğunu göstermektedir.

$S S_{t t}=f f\left(\pi \pi_{t t}, m_{t t}, R R_{t t}, \varepsilon \varepsilon_{t t}\right), f f \pi \pi>0, f f r r<0, f f^{R R}<0, f f \varepsilon \varepsilon>0$ 
(13) numaralı eşitlikte döviz kurlarını $\left(S S_{t t}\right)$ etkileyen başlıca değişkenler tanımlanmıştır. Buna göre nominal kurlar enflasyon $\left(\pi \pi_{t t}\right)$ ve spekülatif şokların $\left(\varepsilon \varepsilon_{t t}\right)$ pozitif, reel faiz oranları $\left(n_{t t}\right)$ ve merkez bankası rezervlerinin $\left(R_{t t}\right)$ negatif fonksiyonudur.

$F F_{t}^{d d}=f f\left(\pi \pi_{t t}, m_{t t}, S S_{t t}, \varepsilon \varepsilon_{t t}, k k_{t t}\right), f f \pi \pi>0, f f r r<0, f f S S>0, f f^{\varepsilon \varepsilon}>0, f f^{\kappa k}<0$

(14) numaralı eşitlik ise, yerleşiklerin yurtiçi döviz mevduatlarının $\left(F_{t}^{d d}\right)$, enflasyonun $\left(\pi \pi_{t t}\right)$, spekülatif şokların $\left(\varepsilon_{t t t}\right)$ ve kurların $\left(S S_{t t}\right)$ pozitif, reel faiz oranları $\left(m_{t t}\right)$ ve yerleşiklerin güven düzeyinin $\left(k k_{t b}\right)$ negatif fonksiyonu olduğunu gösterir. Yerlesiklerin ekonomiye güveni enflasyon

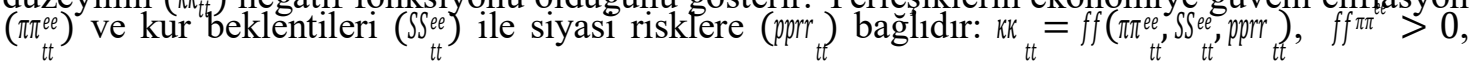
$f f^{s s^{e e}}>0, f f^{p p r r}>0$ (Bkz. Ramon-Ballester ve Wezel 2007).

Görüldüğü gibi (12), (13) ve (14) numaralı fonksiyonel ilişkiler, bunları meydana getiren değişkenler nedeniyle karşılıklı ilişki içerisindedir. Dolayısıyla bu ilişkileri analiz edebilmek için bunları değişkenlerin fonksiyonel etkileşimlerini gösterecek şekilde parametrize ederek aşağıdaki gibi eşanlı bir denklem sistemi oluşturabiliriz:

$$
\begin{aligned}
& R R_{t t}=\alpha \alpha_{11}-\beta \beta_{12} \mu_{t t}+\beta \beta_{13} F_{t} F_{t d}+\beta \beta_{14} \delta \delta_{t t}+\xi \xi_{1 t t} \\
& S S_{t t}=\alpha \alpha_{21}+\beta \beta_{22} \pi \pi_{t t}-\beta \beta_{23} m_{t t}-\beta \beta_{24} R R_{t t}+\beta \beta_{25} \varepsilon \varepsilon_{t t}+\xi \xi_{2 t t} \\
& F F_{t}^{d d}=\alpha \alpha_{31}+\beta \beta_{32} \pi \pi_{t t}-\beta \beta_{33} m_{t t}+\beta \beta_{34} S S_{t t}+\beta \beta_{35} \varepsilon \varepsilon_{t t}-\beta \beta_{36} k \kappa_{t t}+\xi \xi_{3 t t}
\end{aligned}
$$

$\mathrm{Bu}$ denklem sistemine temel teşkil eden fonksiyonel ilişkiler literatürde genellikle teorik olarak ele alınmış ve bazı politik çıkarımlar yapılmıştır. Söz konusu fonksiyonel ilişkilerin geçerliliklerinin Türkiye özelinde deneysel olarak sınanabilmesi için makro modellerin parametre tahminlerinde yaygın olarak kullanılan eşanlı denklem sistemi yaklaşımı benimsenmiştir. Dolayısıyla, tümüyle orijinal olmasa bile, bu analiz yaklaşımının teorik modellerin deneysel dayanaklarının tesis edilmesine bir örnek olması bakımından literatüre katkısı olabilir.

\subsection{Analiz Yöntemi}

Literatürde eşanlı denklem sistemlerinin parametreleri çeşitli tahmincilerle hesaplanabilir. Uygulamalı çalışmalarda genellikle iki (two stage / 2SLS) veya üç aşamalı en küçük kareler (three stage least squares / 3SLS) tahmincileri tercih edilmektedir. Bununla beraber, sıradan en küçük kareler (ordinary least squares / OLS), en yüksek olabilirlik (maximum likelihood / ML) veya genelleştirilmiş momentler yöntemi (generalized method of moments / GMM) gibi tahminciler de kullanılabilir. Bu bağlamda (15), (16) ve (17) numaralı eşitliklerden meydana gelen denklem sisteminin parametreleri iki ve üç aşamalı en küçük kareler tahmincisiyle yapılacaktır. Ancak sonuçların karşılaştırmalı bir değerlendirmesinin yapılabilmesi için sıradan en küçük kareler ve en yüksek olabilirlik tahmincileri de kullanılacaktır.

\subsection{Veri Seti ve Kaynakları}

Çalışmada kullanılan veriler, TCMB'nin resmi internet sitesindeki Elektronik Veri Dağıtım Sisteminden temin edilmiştir. Analiz sürecinde spekülatif şokları $\left(\varepsilon \varepsilon_{t t}\right)$ ve yerleşiklerin güven düzeyini $\left(k k_{t t}\right)$ temsil eden gölge değişkenler haricindeki tüm değişkenler, hesaplama sürecine logaritmik birinci fark dönüşümü uygulanarak dahil edilmiştir. Söz konusu gölge değişkenler ise, tarafımızca hesaplanmıştır. ABD dolarının tüm dünyada en yaygın ve etkili rezerv para birimi olması dolayısıyla dolar arz veya talebindeki ani ve yüksek değişmelerinin gelişmekte olan ülkelerde kur şoklarına yol açması olasıdır. 
Tablo 1. Değişken Tanımlamaları ve Kaynakları

\begin{tabular}{|c|c|c|c|}
\hline & Değişken & Uygulanan Dönüşüm & Veri Kaynağ1 \\
\hline$R R_{t t}$ & Merkez Bankası rezervleri & Logaritmik 1. fark & TCMB \\
\hline$S S_{t t}$ & ABD Doları alış kuru & " $\quad$ " $\quad$ " & “ $،$ \\
\hline$F F_{t t}^{d d}$ & $\begin{array}{l}\text { Bankalardaki döviz tevdiat } \\
\text { hesapları }\end{array}$ & “ & “ \\
\hline$\mu \mu_{t t}$ & Banka kredileri & 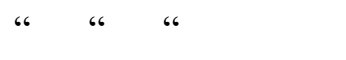 & " $\quad ،$ \\
\hline$\delta \delta_{t t}$ & $\begin{array}{l}\text { Döviz mevduatlarına uygulanan } \\
\text { zorunlu karşıllı oranı }\end{array}$ & “ & " $\quad$ " \\
\hline$\pi \pi_{t t}$ & Tüketici fiyat enflasyonu & ، 6 & “ \\
\hline$r_{\mathrm{tt}}$ & $\begin{array}{l}\text { Bankalardaki TL mevduatlara } \\
\text { uygulanan ortalama faiz oranı }\end{array}$ & " $\quad$ " & “ \\
\hline$\varepsilon \varepsilon_{t t}$ & Spekülatif kur şoku & Gölge değişken & St. Louis FED, FRED \\
\hline$k k_{t t}$ & Yerleşiklerin güven şoku & “ & TCMB \\
\hline
\end{tabular}

Bu bağlamda, ABD Merkez Bankası'nın (FED) para politikasındaki dramatik değişimlerin spekülatif şoka neden olacağı varsayılmış ve FED politika oranında bir önceki döneme göre \pm 2 standart sapmalık değişimler "1" diğerleri " 0 " olarak tanımlanmıştır. Yerleşiklerin güven düzeyine dayalı şokları tanımlamak içinse, TCMB tarafından hesaplanan Tüketici Güven Endeksi kullanılmıştır. Endeks değerinde bir önceki döneme göre \pm 2 standart sapmalık değişimler "1" diğerleri " 0 " olarak tanımlanmıştır. Analizlerde kullanılan değişkenler ve kaynakları Tablo 1'de sunulmuştur.

\subsection{Bulgular}

Analizlerin ilk aşamasında gölge değişkenler haricindeki tüm değişkenlere birim kök sınamaları uygulanarak durağanlıkları araştırılmıştır. Bu bağlamda genişletilmiş Dickey - Fuller, Phillips Peron ve Kwiatkowski - Phillips - Schmidt - Shin (KPSS) birim kök testleri uygulanmıştır. Test sonuçları Tablo 2'de sunulmuştur. Bunlar incelendiğinde tüm değişkenlerin düzeyde durağan oldukları belirlenmiştir. Her ne kadar $R R_{t t}$, $S S_{t t}$ ve $\mu_{t t}$ değişkenleri KPSS testine göre sabit içeren sınama modeli için durağan değillerse de trend içeren sınama modeli için durağandırlar. Söz konusu değişkenler trend içerdiklerinden sabit ve trend içeren test sonuçlarına itibar edilmelidir. Aslında değişkenlerin tümünün logaritmik birinci farkları alınarak analizlere dahil edilmeleri nedeniyle durağan olmaları şaşırtıcı değildir.

(15), (16) ve (17) numaralı eşitliklerden meydana gelen denklem sisteminin alternatif tahmincilerle parametre tahminleri yapılmış ve sonuçlar Tablo 3 'de sunulmuştur. Tahmin sonuçları, modelde yer alan çoğu parametrenin tahminlerinin istatistik anlamlılıklarının yüksek olduğunu göstermektedir. Anlamlı bulunmayan parametrelerin kullanılan tahminciye göre değiştiği görülmüştür. Bununla beraber yüksek oranda anlamlı bulunan parametreler tüm tahmincilerle yapılan hesaplamalarda genelde aynıdır. Sistemdeki denklemler bazında tahminlerin açıklama gücü sınırlı olsa da fazla sayıda parametresi olan ve bunların eş anlı olarak tahmin edildiği bir model için bu durum makul sayılabilir.

Tahmin sonuçları incelendiğinde, modelin parametrelerinin büyük oranda öngörülen fonksiyonel ilişkileri doğruladığı görülür. Ancak faiz oranının kurlar ve döviz mevduatları üzerindeki negatif etkileri somut bir şekilde kanıtlanamamıştır. Enflasyonun döviz mevduatları üzerindeki etkisi de 
2AEK tahmini haricinde beklenin tersine negatif bulunmuştur. Alternatif tahminciler arasındaki farklılıklar da genelde bu gibi değişkenler bakımından gözlenmektedir. Yani genellikle anlamsız bulunan değişkenler kullanılan tahminciye göre çelişkili katsayı işaretleri vermiştir. Bunlar haricinde diğer fonksiyonel ilişkiler beklendiği gibidir. Dolayısıyla Mizen'in (1999) modelinde ileri sürdügü fonksiyonel ilişkilerin büyük oranda Türkiye için geçerli olduğu söylenebilir.

$\mathrm{Bu}$ çerçevede, yurtiçi kredi büyümesi ile merkez bankası rezervleri azalmaya başlayacaktır. Çünkü kurların arttığı bir çevrede kredilerin döviz talebini uyarma olasılığı yüksektir. Oysa rezervler, kurların merkez bankasının hedeflediği seviyelerde tutulmasının başlıca teminatıdır. Rezervlerin düşmesi, bankalarda döviz mevduatları olanların güvenlerinin azalmasına ve dövizin banka sistemi dışına çıkmasına neden olabilir. Sonuçta merkez bankası giderek kontrol gücünü kaybeder. Ulaştığımız bulgular, bu tespitlerin Türkiye için de geçerli olduğunu göstermektedir.

Sürecin temelinde fiyat istikrarı vardır. Enflasyon oranları makul seviyelere düşürülmedikçe, er ya da geç yukarıda özetlenen gelişmeler yaşanacaktır. Elde ettiğimiz bulgular, Türkiye'de enflasyonun kurlar üzerindeki etkisini açıkça ortaya koymaktadır. Enflasyonun döviz mevduatlarını doğrudan etkilediğine dair somut bulgulara ulaşılamamıştır. Ancak doğrudan olmasa bile kurlar kanalıyla enflasyon mevduatları dolaylı bir şekilde etkilemektedir. 
Tunay, K. B. (2022). 9/1, 57-73

Tablo 2. Birim Kök Testlerinin Sonuçları

\begin{tabular}{|c|c|c|c|c|c|c|c|}
\hline & \multicolumn{3}{|c|}{ ADF Testleri } & \multicolumn{2}{|c|}{ Phillips-Perron Testleri } & \multicolumn{2}{|c|}{ KPSS Testleri } \\
\hline & t Testi & $\mathrm{p}$ Değeri & Gecikme & t Testi & p Değeri & Sabit & Sabit + Trend \\
\hline$R R_{t t}$ & -13.1045 & 0.0000 & 0 & -13.2288 & 0.0000 & 0.6034 & 0.0241 \\
\hline$S S_{t t}$ & -11.5438 & 0.0000 & 1 & -10.1625 & 0.0000 & 0.5764 & 0.0312 \\
\hline$F F_{t t}^{d d}$ & -13.2169 & 0.0000 & 1 & -16.7767 & 0.0000 & 0.1523 & 0.0296 \\
\hline$\mu \mu_{t t}$ & -4.1943 & 0.0000 & 5 & -13.3123 & 0.0000 & 0.9475 & 0.0604 \\
\hline$\delta \delta_{t t}$ & -8.3400 & 0.0000 & 3 & -14.3384 & 0.0000 & 0.2172 & 0.0507 \\
\hline$\pi \pi_{\mathrm{tt}}$ & -7.5848 & 0.0000 & 3 & -10.3563 & 0.0000 & 0.3306 & 0.2668 \\
\hline$r r_{t t}$ & -8.4152 & 0.0000 & 3 & -14.3449 & 0.0000 & 0.2305 & 0.0531 \\
\hline$\varepsilon \varepsilon_{t t}$ & \multicolumn{7}{|c|}{$\leftarrow$ gölge değişken } \\
\hline$\kappa \kappa_{t t}$ & \multicolumn{7}{|c|}{$\leftarrow$ gölge değişken } \\
\hline \multicolumn{8}{|c|}{ Kritik Değerler: } \\
\hline $5 \%$ & -2.8740 & & & -2.8739 & & 0.463 & 0.146 \\
\hline $10 \%$ & -2.5735 & & & -2.5734 & & 0.347 & 0.119 \\
\hline
\end{tabular}


Tablo 3. Tahmin Sonuçları

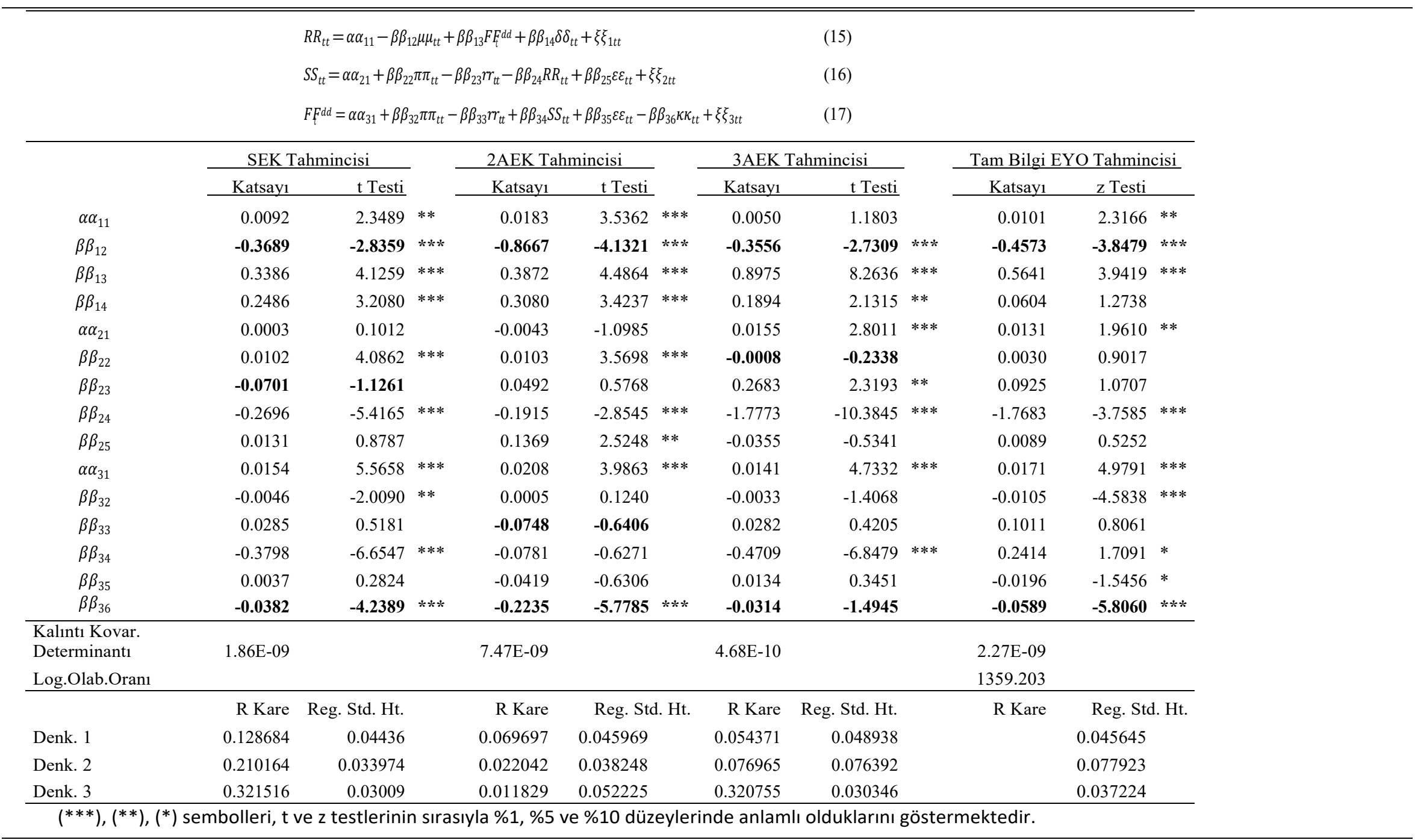




\section{Sonuç}

Bu çalışmada, Türkiye'de banka sistemindeki döviz mevduatları üzerinden para ikamesi süreci deneysel olarak analiz edilmiştir. Mizen'in (1999) teorik modeli temel alınarak Türkiye'de banka sistemi merkezli para ikamesi sürecinin dinamikleri araştırılmıştır. Kurulan eşanlı denklem sistemi, 2002:5 ile 2021:7 dönemi aylık verileri kullanılarak alternatif tahmincilerle çözülmüştür. Ulaşılan bulgular, makul bir istatistik anlamlılık düzeyindedir ve Mizen'in modelinde ileri sürülen fonksiyonel ilişkilerin Türkiye için büyük oranda geçerli olduğunu göstermiştir.

Başlıca kırılganlık odakları yüksek ve kronik enflasyon ile buna eşlik eden yüksek cari açık olan Türkiye ekonomisinin, spekülatif kur atakları karşısında ciddi bir döviz krizine girme olasılığ oldukça yüksektir. Türk bankacılık sisteminin yüksek döviz yükümlülükleri ile böyle bir şok karşısında krize girme potansiyeli de göz ardı edilemez. Diğer bir deyişle, olası bir kur krizinin banka krizini tetiklemesi mümkündür ve Türkiye için uluslararası kriz literatüründe sıklıkla işaret edilen ikiz kriz riski fazlasıyla yüksektir. Hali hazırda banka sisteminde döviz mevduatlarının toplam mevduatlara oranı \%50'leri aşmıştır. Ayrıca bankaların yurtdışından aldıkları ciddi boyutlarda sendikasyon kredileri de söz konusudur. Bunlar banka sistemi için önemli kırılganlık odaklarıdır.

Türkiye'de kur şoku kaynaklı bir banka krizinin büyüklüğünü, yerleşiklerin ekonomiye dair güven düzeyleri belirleyecektir. Yerleşikler paniğe kapılmadıkça döviz varlıklarını banka sisteminde tutmaya devam edeceklerdir. Böylece kur artışı, bankaların döviz yükümlülüklerinin maliyetini arttırmakla kalacaktır. Merkez bankası rezervleri makul düzeylerde olduğunda bu yönetilebilir bir süreçtir. Mizen'in de işaret ettiği gibi, rezervler olası kur şoklarının etkilerini karşılayamayacak oranda düştüğünde, bankalardaki döviz mevduatlarının çekilmesi ve/veya yurtdışındaki banka hesaplarına aktarılması ile para ikamesi süreci boyut değiştirir. Kur rejiminin çökmesi artık bir zaman meselesidir. Sürecin sonunda hem merkez bankasının parasal kontrol gücü çok büyük oranda düşer hem de banka sistemi ciddi bir türbülansa girebilir.

Diğer yandan, banka sisteminin açtığı kredilerin hacmindeki artışın rezervleri azalttı̆̆ bilinmektedir. Merkez bankası rezervlerinin zaten düşük olduğu bir ortamda, ekonomik büyümeyi teşvik etmek için yurtiçi kredi hacmini arttırmak yukarıda açıklanan süreci çok daha büyük bir çıkmaza götürebilir. Kurların günden güne arttığı bir ortamda, kredi alanların dövize yönelmeleri riski vardır ve böyle bir gelişme kur baskısını şiddetlendirecektir. Para ikamesi veya dolarizasyon süreci tersine çevrilmedikçe veya en azından sürdürülebilir seviyelere indirilmedikçe, banka kredilerini uyarmak ateşe benzin dökmeye benzer. 


\section{Kaynakça}

Agenor, P. R., Khan, M. S. (1996). Foreign Currency Deposits and The Demand for Money in Developing Countries. Journal of Development Economics, 50, 101-118.

Alami, T. H. (2001). Currency Substitution versus Dollarization A Portfolio Balance Model. Journal of Policy Modeling, 23, 473-479.

Arteta, C. O. (2003). Are Financially Dollarized Countries More Prone to Costly Crises? Board of the Governors of the Federal Reserve System, International Finance Discussion Papers, 763.

Bitar, J. (2021). Foreign Currency Intermediation: Systemic Risk and Macroprudential Regulation. Latin American Journal of Central Banking, 2, 100028.

Brown, M., Stix, H. (2015). The Euroization of Bank Deposits in Eastern Europe. Economic Policy, 95-139.

De Nicolo, G., Honohan, P., Ize, A. (2003). Dollarisation of the Banking System: Good or Bad? World Bank Policy Research Working Papers, 3116.

Flood, R. P., Garber, P. M. (1984). Collapsing Exchange-rate Regimes: Some Linear Examples. Journal of International Economics, 17, 1-13.

G Gulde, A. M., Hoelscher, D. S., Ize, A., Marston, D. D., De Nicoló, G. (2004). Financial Stability in Dollarized Economies. IMF Occasional Paper, 230.

Honohan, P., Shi, A. (2003). Deposit Dollarisation and the Financial Sector in Emerging Economies. J. Hanson, P. Honohan and G. Majnoni (Ed.). Globalization and National Financial Systems. New York: The World Bank ve Oxford University Press.

Mirakhor, A., Zaidi, I. (2004). Foreign Currency Deposits and International Liquidity Shortages in Pakistan. IMF Working Papers, 04/167.

Mizen, P. (1999). Can Foreign Currency Deposits Prop up a Collapsing Exchange-rate Regime? Journal of Development Economics, 58, 553-562.

Ramon-Ballester, F. ve Wezel, T. (2007). International Financial Linkages of Latin American Banks: The Effects of Political Risk and Deposit Dollarization. ECB Working Papers, 744.

Versal, N., Stavytskyy, A. (2015). Financial Dollarization: A Trojan Horse for Ukraine? Ekonomika, 94(3), 21-45.

Whited, H. I. H. (2004). Comment on 'Currency Substitution versus Dollarization: A Portfolio Balance Model'. Journal of Policy Modeling, 26, 113-116. 